\title{
PILOT TESTING OF THE CZECH VERSIONS OF THE COACHING BEHAVIOR ASSESSMENT QUESTIONNAIRE STRUCTURE
}

\author{
Veronika Baláková, Martin Musálek
}

Faculty of Physical Education and Sport, Charles University, Prague, Czech Republic

Submitted in January, 2012

BACKGROUND: In the sports environment, the opinion that the leadership style of the coach plays an essential role in achieving team success is generally accepted (Amorose \& Horn, 2001). Scott Martin and Kelly Barnes in 1999 created Coaching Behavior Assessment Questionnaire, based on CBAS (Smith et al., 1977) and LSS (Chelladurai \& Saleh, 1978, 1980). Currently in the Czech Republic, there is no diagnostic tool that would address the effectiveness of the coach.

OBJECTIVE: The purpose of this pilot study was to translate and evaluate the structure of CBAQ by method of structural equation modeling for population of children in age 10-16.

METHODS: For translation of the questionnaire we utilized a modified direct translation method (Behling \& Law, 2000). A total of 100 participants age 10 to 16 , female 63 (mean age 13.02, $\mathrm{SD}=2.10$ ), male 37 (mean age 13.27 , $\mathrm{SD}=1.37$ ) completed the CBAQ. For data analysis we applied both exploratory and confirmation factor analysis approaches.

RESULTS: The original model was tested to verify the structural theory and diagnosis quality of this tool. Results of the original CBAQ 12 factor model showed poor fit of the underaverage values RMSEA on the level 0.082, CFI on the level 0.600 and lack coefficients of generic reliability. After reanalyzing the data we established a modified 5 factor structure of CBAQ. This 5 factor model with restricted numbers of items gave the best values of fit RMSEA $=0.056$, $\mathrm{CFI}=0.964$ and acceptable values of generic reliability.

CONCLUSIONS: This study had pilot character and we were aware of problems with loosing information due to very restricted numbers of items in modified version, however it is suggested that final 5 factor version with 15 items could made basis for future full standardized Czech version of CBAQ.

Keywords: Behavior of coach, cross cultural validation, face-validity, content validity, structural equation modeling, reliability.

\section{INTRODUCTION}

In the sports environment, the opinion that the leadership style of the coach plays an essential role in achieving team success is generally accepted (Amorose \& Horn, 2001).

Over the last few decades different research projects were held in order to identify factors that influence the effectiveness of the coach (leader) (e.g. Chelladurai \& Saleh, 1978; Mondello \& Janelle, 2001; Smith, Smoll, \& Hunt, 1977). Some studies have focused on the conditions, antecedents that influence the behavior of a leader (coach). According to Chelladurai (1990) these are situational characteristics (type of sport, organizational goals, socio-cultural environment), leader characteristics (age, gender, experience, personality) and characteristics of members (age, gender, skill level, psychological characteristics). Other studies have focused on the consequences of the leader's behavior (coach), which means, how the behavior of a leader (coach) affects the performance of his athletes, and their satisfaction (e.g. Amorose, 2007; Baker, Yardley, \& Côté, 2003; Gillet,
Vallerand, Amoura, \& Balds, 2010; Martin, Jackson, Richardson, \& Weiller, 1999).

Probably the best known diagnostic tools in this area are Meditational model of leadership that was created by the authors Smith, Smoll, and Hunt (1978) and Multidimensional model of leadership, Chelladurai and Saleh (1978). Although these two models are generally accepted by experts, each of them has a fundamentally different approach in the evaluation of the work of coaches. Smith et al. created the Coaching Behavior Assessment System (CBAS; Smith et al., 1977), which evaluates the coach's behavior based on participative structured observations. In addition, in order to obtain more data sources, the athlete can be asked for verbal description of a situation and can be also asked how often a coach uses this type of behavior. Athlete evaluates on 7 point Likert scale from never (1) to almost always (7).

Based on this multi-dimensional model, created later Chelladurai and Saleh Leadership Scale for Sport (LSS, Chelladurai \& Saleh, 1980), which evaluates the coach's behavior based on results of questionnaires for coaches 
and their athletes. The authors argued that the input (antecedent) characteristics (i.e. situational, leader, and member) in combination with the characteristics of leadership (coach) behaviors (i.e., required, actual, and preferred) determine the athlete/team performance and satisfaction (consequences). There are three versions of the LSS, (a) version for a coach, where he tries to describe his own behavior, (b) version for athletes, where they try to describe the coach's behavior, (c) the preferred version, where athletes try to describe behavior that they would prefer in their trainer.

The Multidimensional model of leadership (Chelladurai \& Saleh, 1978, 1980) was subsequently slightly modified by Martin et al. (1999). They included parents in the model for the first time, creating a version of the questionnaire, which deals with the preferred style of coaching behavior on the part of parents.

Scott Martin and Kelly Barnes then in 1999 at the University of North Texas in the U. S. created Coaching Behavior Assessment Questionnaire, based on CBAS (Smith et al., 1977) and LSS (Chelladurai \& Saleh, 1978, 1980). The authors speculated whether connecting these two approaches would result in better conclusions for the evaluation of coaches.

\section{Coaching Behavior Assessment Questionnaire}

The CBAQ was originally created and is used for the population aged 10 to 23 years. Like LSS, CBAQ was also designed to detect three variants of the coach's leadership: a) required, b) actual, c) preferred.

Coaching Behavior Assessment Questionnaire is composed of two parts. The first part contains 12 demographic items, then the second part 48 items related to elements of the coach's behavior. The 12 demographic items talk not only about the athlete's age, gender, race or sport performed but also the preference of gender and age of coach. The 48 items measure perception of selected elements of the coach's behavior and is divided into 12 categories, each category is expressed by four items. Twelve categories, which are divided into 48 items, correspond with the 12 categories of the coach's behavior represented in CBAS (Smith et al., 1977). Responses to all 48 items are recorded on 5 point Likert scale ranging from strongly disagree (1) to strongly agree (5). All 48 items are always equally applied to all variants of the questionnaire, only an introduction to each item varies. The required version begins with "Coach..." (Coach says statements like "way to go" when athlete is doing well). The current version starts with "My coach..." (My coach says statements like "way to go" when athlete is doing well). The preferred version then begins, "I prefer coach..." (I prefer a coach who says statements like "way to go" when athlete is doing well). Altogether CBAQ has 8 versions - three versions of the desired behavior (option for athletes, the coach or the parents), three of the actual behavior (option for athletes, the coach or the parents) and two versions of the preferred behavior (option for athletes and for parents). The reason for the creation of these various options is ability to determine what the coach should have done (how he should have behaved) at a specific level, how he actually behaves and also what is required of him. That is why CBAQ combines categories of behavior from CBAS (Smith et al., 1977) and multidimensionality resulting from the LSS (Chelladurai \& Saleh, 1978, 1980).

Studies by Martin et al. (2001), in which a questionnaire CBAQ was used shows that athletes prefer such coach's behavior, which falls into the category of reinforcement, general encouragement, and general technical instruction. Further studies examined the effect of gender and type of sport on the coachs preferred behavior (Kravig, 2003).

\section{RESEARCH PROBLEMS}

Currently in the Czech Republic, there is no diagnostic tool that would address the effectiveness of the coach. For this reason it was decided to translate and evaluate the structure of CBAQ by method of structural equation modeling for population of children in age 10-16. Given the complexity of the process of the validation study, we have decided only to execute the pilot verification of CBAQ structure. Results and conclusions of this pilot investigation subsequently served as a basis for creating a modified version of the questionnaire CBAQ.

\section{METHODS}

Fig. 1

Original structure of CBAQ questionnaire

\begin{tabular}{|c|c|c|c|c|}
\hline & Categories & \multirow{2}{*}{$\rightarrow$} & Items & \\
\hline 1. & Reinforcement & & $1,13,25,37$ & 1. \\
\hline 2. & Non-reinforcement & \multirow{2}{*}{$\begin{array}{l}\longrightarrow \\
\longrightarrow\end{array}$} & $2,14,26,38$ & 2. \\
\hline 3. & $\begin{array}{l}\text { Mistake-contingent } \\
\text { encouragement }\end{array}$ & & $3,15,27,39$ & 3. \\
\hline 4. & $\begin{array}{l}\text { Mistake-contingent } \\
\text { technical instruction }\end{array}$ & \multirow{2}{*}{$\begin{array}{l}\longrightarrow \\
\longrightarrow\end{array}$} & $4,16,28,40$ & 4. \\
\hline 5. & Punishment & & $5,17,29,41$ & 5. \\
\hline 6. & $\begin{array}{l}\text { Punitive technical } \\
\text { instruction }\end{array}$ & \multirow{2}{*}{$\begin{array}{l}\longrightarrow \\
\longrightarrow\end{array}$} & $6,18,30,42$ & 6. \\
\hline 7. & Ignoring mistakes & & $7,19,31,43$ & 7. \\
\hline 8. & Keeping control & \multirow{2}{*}{$\begin{array}{l}\longrightarrow \\
\longrightarrow\end{array}$} & $8,20,32,44$ & 8. \\
\hline 9. & $\begin{array}{l}\text { General technical } \\
\text { instruction }\end{array}$ & & $9,21,33,45$ & 9. \\
\hline 10. & General encouragement & \multirow{2}{*}{$\longrightarrow$} & $10,22,34,46$ & 10. \\
\hline 11. & Organization & & $11,23,35,47$ & 11. \\
\hline 12. & General communication & $\rightarrow$ & $12,24,36,48$ & 12. \\
\hline
\end{tabular}




\section{Participants}

In the study 100 players of a youth volleyball from Prague and Pilsen aged 10 to 16 years, female 63 (mean age 13.02, $\mathrm{SD}=2.10$ ), male 37 (mean age 13.27, $\mathrm{SD}=1.37$ ) participated. For research, we used the method of intended selection. The first criterion was the age of athletes, which had to be $10-16$ because CBAQ is determined for this population. Second criterion was the skill level of athletes. Athletes had to play a regional championship or Czech Cup.

The informative agreements of children parents and confirmation from ethic committee were obtained.

\section{Translation of the questionnaire}

The questionnaire was translated by three experts in the field of physical education and sport. For this purpose were used the modified direct translation procedure (Behling \& Law, 2000) in combination with the protocol analysis (Hines \& Snowden, 1993).

In phase 1, three experts worked independently. Professionals were presented with the instructions to translate the text based on the meaning rather than word by word.

In phase 2, translations from all three translators were reviewed by the researcher who added additional notes. The entire content was then returned back to the translators for clarifications.

In phase 3, all three experts met with the main researcher. Individual items were then discussed in relation to meaning and grammar. The result of this meeting was the first Czech version of the questionnaire.

In phase 4, was the first Czech version of the questionnaire given to language professionals to review. The second version was then created on the basis of their proposals.

Because of the identified shortcomings of the content and face validity, we did not include the next phase i.e. the distribution and administration of the second version of the questionnaire, relating to the clarity of items.

\section{Factorial validity and reliability}

The factor structure was tested by means of structural equation modeling. We applied the confirmatory approach for categorical data. We used statistical program M-plus version 6.0 which represents a suitable statistical tool for modeling with latent variables (Muthen \& Muthen, 2010). The main idea is to verify relationship between the unobserved latent variable called mathematically factor and observed variables - items. This relationship is expressed by regression coefficients called factor validity (Lawley \& Maxwell, 1971; Rao \& Sinharay, 2007).

The original model was tested to verify the structural theory and diagnosis quality of this tool which assess coaching behavior. Since our data are categorical ordi- nal, Muthen (1984) we recommend using for parameters of estimation, the method of Weighted least square parameter estimates using a diagonal weight matrix with standard errors and mean and variance adjusted chisquare test statistic that use a full weight matrix. Fit of the model was expressed by several fit indices, Sattora-Bentler chi-square, Comparative Fit Index (CFI), (Bentler, 1990) and Root Mean Square of Approximation (RMSEA) (Steiger, 1990). Authors Browne and Cudeck (1993) describe index CFI as coefficient with value between $0-1$, value 0.90 and higher indicate good fit of model. Values of RMSEA lower than 0.05 show a very good fit, $0.05-0.08$ good fit, $0.08-0.10$ average fit and higher than 0.10 indicate bad fit of the model. Other indices we used were SRMR, Standardized Root Mean Residual for exploratory approach (recommended value $\leq$ 0.07) (Jöreskog \& Sörbom, 1988). The SRMR is an absolute measure of fit and a value of zero indicates perfect fit. The SRMR has no penalty for model complexity. A value less than .08 is generally considered a good fit (Hu \& Bentler, 1999).

Another fit indices which were recommended by Keith (1997) were used, TLI Tucker-Lewis index also called the non-normed fit index and WRMR Weighted Root Mean Square Residual (recommended value $\leq 1$ ) (Keith \& Witta, 1997).

Approximation of generic reliability of each construct was performed by computing of coefficient McDonalds omega (McDonald, 1991).

\section{The process of testing}

The translated questionnaires were gradually distributed to players from 10 volleyball clubs at the end of the training unit.

During the administration of the test, our assumptions were confirmed regarding the inadequate content validity, and there were three main categories of problems:

1. Items no. 2, 7, 14, 19, 31, 38, 43 contained negatives, causing many players not to be able to adequately respond on the Likert's scale (instead of 5 checked 1 , instead of 4 checked 2, etc.);

2. Items no. $25,31,42,46$ contained expressions, which especially the younger athletes did not understand (no. 25, 46 - that the appraisement is not a material gift, but the expression of praise or recognition) or did not know them at all; no. 31 - emotions; no. 42 sarcasm);

3. Content and meaning of items no.11, 20, 23, 32, 40, 43, 47 especially younger athletes did not understand;

These three categories of problems have been detected from repeated queries from male players and female players and also from random individual inter- 
TABLE 1

CFA 12 factor model of original version of CBAQ

\begin{tabular}{|c|c|c|c|c|c|c|}
\hline Model & Chi-square & Df & CFI & TLI & RMSEA & WRMR \\
\hline 12 factors & 1248.386 & 1014 & 0.600 & 0.555 & 0.082 & 1.225 \\
\hline
\end{tabular}

Legend: $\mathrm{CFI}=$ Comparative fit index (recommended value $\geq 0.95), \mathrm{TLI}=$ Tucker-Lewis index (recommended value $\geq 0.95), \mathrm{RMSEA}=$ Root Mean Square of Approximation (recommended value $\leq 0.08$ ), WRMR = Weighted Root Mean Square Residual (recommended value $\leq 1.00)$

views with selected players by the administrator, when he asked them controlling questions (e.g. no. 2 - "Does not say encouraging remarks during the game", a player scored a 4 - "I agree" the administrator asked - "Does the coach encourage you during a game?" the player replied "yes" in the questionnaire should therefore be scored 2 - "I do not agree").

Given the assumption that not always and not all athletes who needed help asked for it, it is likely that the above problems could affect the results of analysis of the original version CBAQ.

\section{RESULTS}

\section{Factorial validity and fit of the model of original version} CBAQ

The outcomes from structural equation modeling (Appendix 1) suggested that a twelve dimensional structure with the original 48 items indicated lack values of fit of the model. Additionally comparing our results with data provided by authors of CBAQ there are a lot of differences. In our study the index of fit RMSEA on the level 0.082 express only average fit. This value was much lower in comparing of RMSEA $=0.052$ in original study. Other index of fit, CFI $=0.600 \mathrm{TLI}=0.555$ and $\mathrm{WRMR}=1.225 . \mathrm{CFI}$ were even very under average and showed that there are some problems in structure in our study. As well as chi-square $=1248.386$. These results may imply from sample size $\mathbf{N}=100$ as well as from problems with content and face validity of several items, its difficulty and understanding by participants which we suggested in the Methods section - process of testing.

From Appendix 1 is also evident that there is 13 indicators which have poor factor validity, lower than 0.40 . Furthermore in our structural model we discovered a lot of strong correlations between latent variables (factors) (Appendix 2). This finding indicates that each pair of constructs is indicating similar or even the same latent areas.

\section{Reliability}

In this study it was generally found that lower coefficients of generic reliability ranged from 0.44 to 0.79 in comparison with the original CBAQ from 0.62 to
0.95 . The poorest generic reliability on the level 0.44 was found at the tenth dimension called General Encouragement (Ge-en).

\section{TABLE 2}

Generic reliability of latent variables

\begin{tabular}{|l|c|}
\hline Constructs & $\begin{array}{c}\text { Generic reliability, } \\
\text { McDonald } \omega\end{array}$ \\
\hline Reinforcement & $\mathbf{0 . 7 9}$ \\
\hline Non-reinforcement & 0.64 \\
\hline Mistake-contingent encouragement & 0.56 \\
\hline Mistake-contingent technical instruction & 0.68 \\
\hline Punishment & 0.62 \\
\hline Punitive technical instruction & 0.60 \\
\hline Ignoring mistakes & $\mathbf{0 . 7 5}$ \\
\hline Keeping control & 0.49 \\
\hline General technical instruction & $\mathbf{0 . 7 8}$ \\
\hline General encouragement & 0.44 \\
\hline Organization & $\mathbf{0 . 7 7}$ \\
\hline General communication & 0.62 \\
\hline
\end{tabular}

\section{Modification of original CBAQ diagnostics tool}

Based on the results of structural modeling of the original version of CBAQ potential problems were confirmed with content validity, face validity and problems of clarity and complexity of some items that players had when filling in CBAQ. After finding the unacceptable values fit indices, the original model structure of CBAQ was dismissed and it was proceeded to the modification of the tool CBAQ, which was comprised of the following steps:

1. The selected expressions in items no. $25,31,42$, 46 the athletes did not understand; items no. 25, 46 were retained in the questionnaire, for the reason that the behavior of a coach who shows praise, the athletes of the age mentioned above are able to identify very well and has for them and their learning process a very crucial meaning (Black \& Weiss, 1992); item no. 42 remained in the questionnaire as well, although children often fail to identify this type of behavior, it means that 
Appendix 1

Structural model of CBAQ, squares represent individual items, ovals latent factors, the arrows represent relationships between items and latent variables

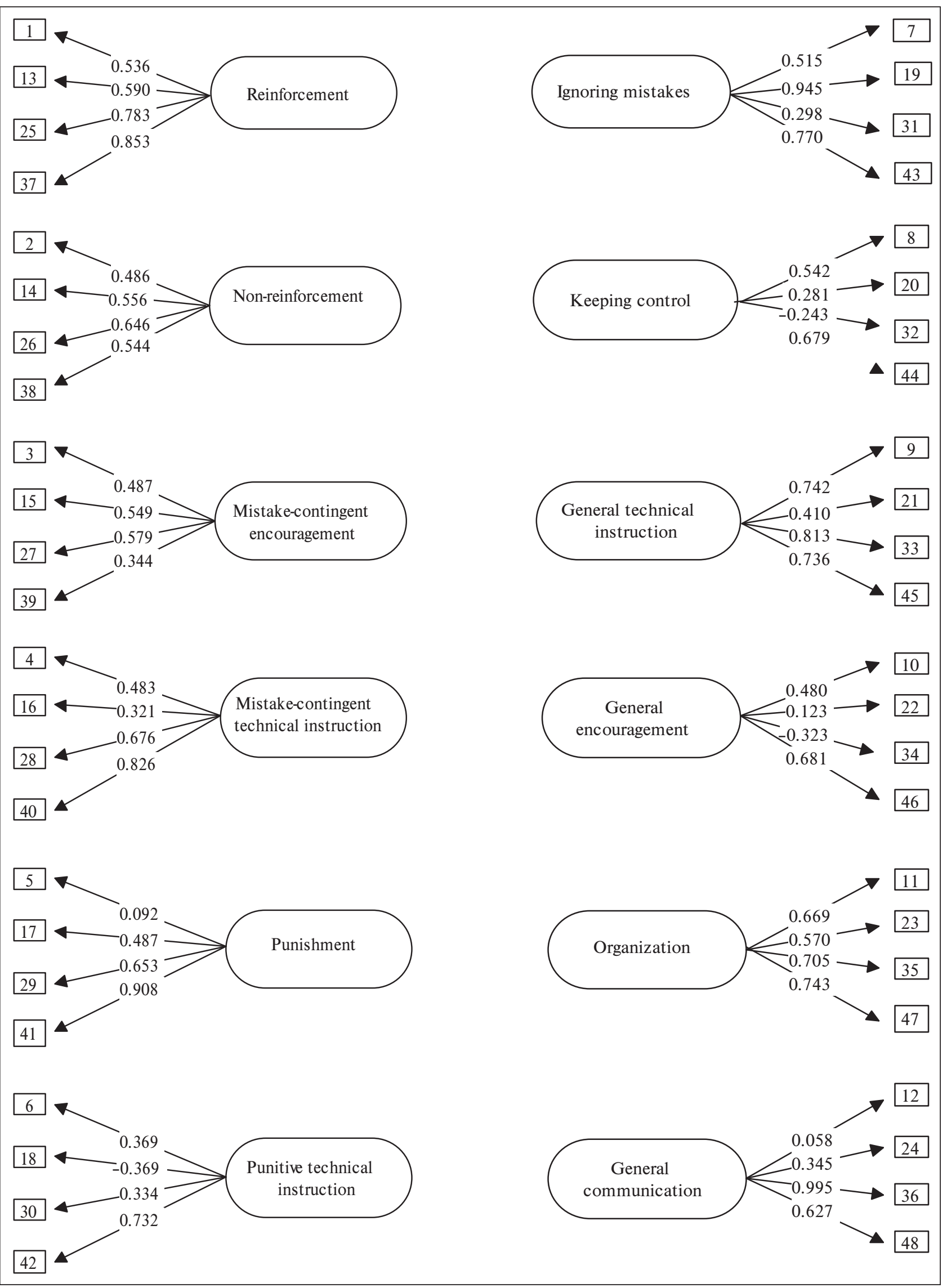


Appendix 2

Correlation matrix of latent variables (factors) with highlighted strong correlations between factors

\begin{tabular}{|l|r|r|r|r|r|r|r|r|r|c|c|c|}
\hline & Rei & Non re & Mi-co-e & Mi-co-t-i & Pun & Pun-t-i & Ig-mi & Kee-co & Ge-te- $i$ & Ge-en & Org & Ge-com \\
\hline Rei & \multicolumn{1}{c|}{1} & & & & & & & & & & & \\
\hline Non re & $\mathbf{- 0 . 9 9 9}$ & 1 & & & & & & & & & & \\
\hline Mi-co-e & 0.542 & 0.542 & 1 & & & & & & & & & \\
\hline Mi-co-t- $i$ & $\mathbf{0 . 9 2 1}$ & $\mathbf{- 0 . 9 2 7}$ & 0.102 & 1 & & & & & & & & \\
\hline Pun & -0.520 & 0.238 & -0.654 & 0.150 & 1 & & & & & & & \\
\hline Pun-t-i & $\mathbf{0 . 9 9 8}$ & $\mathbf{0 . 9 7 9}$ & 0.369 & -0.849 & $\mathbf{0 . 9 9 6}$ & 1 & & & & & & \\
\hline Ig-mi & -0.727 & $\mathbf{0 . 9 9 8}$ & 0.272 & -0.552 & 0.000 & 0.545 & 1 & & & & & \\
\hline Kee-co & $\mathbf{0 . 9 7 7}$ & $\mathbf{- 0 . 8 6 7}$ & 0.483 & $\mathbf{0 . 9 9 6}$ & $\mathbf{- 0 . 8 5 6}$ & $\mathbf{- 0 . 9 9 9}$ & -0.320 & 1 & & & & \\
\hline Ge-te-i & 0.597 & -0.461 & 0.171 & $\mathbf{0 . 8 9 1}$ & 0.257 & -0.567 & -0.494 & 0.570 & 1 & & & \\
\hline Ge-en & 0.774 & -0.553 & 0.401 & $\mathbf{0 . 9 9 7}$ & 0.058 & $\mathbf{- 0 . 8 3 7}$ & -0.629 & $\mathbf{0 . 9 0 3}$ & $\mathbf{0 . 9 7 0}$ & 1 & & \\
\hline Org & 0.388 & -0.197 & 0.356 & 0.387 & 0.660 & 0.132 & -0.308 & -0.111 & 0.617 & 0.771 & 1 & \\
\hline Ge-com & 0.293 & -0.119 & 0.601 & 0.080 & -0.261 & -0.515 & 0.129 & -0.082 & 0.353 & 0.364 & 0.474 & 1 \\
\hline
\end{tabular}

children may be confused, lost in meanings and subsequently in the organization and cease to be interested in the activity; in order to ensure proper understanding of the two verbal expressions, a word commentary during test administration is suitable; item no. 31 was excluded from the questionnaire (see also section 4);

2. Items no. $11,20,23,32,43,47$ players very often did not understand, did not know what the content of individual questions meant; it is not possible to further verbally explain each item, as well as an adult who has a problem with their understanding; for this reason all items were excluded from the questionnaire; item no. 40 is not properly formulated so as to correspond with the respective category, and thus was eliminated from the questionnaire;

3. Items no. 9, 16, 22, 23, 26, 28, 30, 34, 44, 46 did not fall clearly into the category of the original structure; after a consultation with the principal methodologist and also with the coordinator of youth of the Czech Volleyball Association it was decided on the rearrangement or exclusion of some items:

- no. 9, category $9 \rightarrow$ ?; the item is talking about tactics, strategy, which is not in the field of sports training considered as a synonym of the word technique, therefore, this item should not be included in the category general technical instruction; it is likely that the author of this questionnaire does not distinguish between these two words; this item was excluded from the questionnaire;

- no. 16 - according to the original structure belongs to a category 4 , based on our opinion it rather falls into category 3 ;

- no. 22 , category $10 \rightarrow 1$; the coach's behavior is a reaction to the player's previous performance, the item should not fall into the category of general encouragement;

\section{Appendix 3}

Acronyms of latent variables (factors)

\begin{tabular}{|l|l|}
\hline Reinforcement & Rei \\
\hline Non-reinforcement & Non rei \\
\hline Mistake-contingent encouragement & Mi-co-e \\
\hline Mistake-contingent technical instruction & Mi-co-t-i \\
\hline Punishment & Pun \\
\hline Punitive technical instruction & Pun-t-i \\
\hline Ignoring mistakes & Ig-mi \\
\hline Keeping control & Kee-co \\
\hline General technical instruction & Ge-te-i \\
\hline General encouragement & Ge-en \\
\hline Organization & Org \\
\hline General communication & Ge-com \\
\hline
\end{tabular}

- no. 23 , category $11 \rightarrow$ ?; the author uses the word of strategy of game for an item from the category organization, the item should not belong in this category; the item should be removed from the questionnaire;

- no. 26 , category $2 \rightarrow 4$; the behavior of the coach is a reaction to the player's mistake, it should therefore belong to category 4 ; the item was removed from the questionnaire;

- no. 28 , category $4 \rightarrow 9$; the description of the behavior is not given, that it is a reaction to the behavior of a player, so item should belong to the spontaneous behavior of the coach;

- no. 30 , category $6 \rightarrow 5$; the physical intimidation of players by a coach can be regarded as a punishment rather than just rebuke (punitive instruction);

- no. 34 , category $10 \rightarrow 1$; the coach's behavior is a reaction to the player's previous performance, the item 
should not fall into the category of general encouragement;

- no. 44 , category $8 \rightarrow$ ?; item deals with coach's fairness, which does not correspond with the skill of organizing training; the item was removed from the questionnaire;

- no. 46 , category $10 \rightarrow 1$; if a coach "praises" player, the item should fall into the category of Reinforcement;

4. Items no. $2,7,14,19,31,38$ and 43 contained negative, all of these items were excluded from the questionnaire;

5. Categories no. 2, 4, 7, 8, 10 and 11 were completely excluded from the questionnaire. After selection of items, remained always only one item in these categories, which is sufficient to identify the factor:

- category no. 2 (Non-reinforcement) - included 3 items (no. 2, 14, 38) with negative and 1 item (no. 26) did not fall into this category; this category is the opposite of category 1 and therefore we conclude that there is no need to include both of them, categories 1 and 2 highly correlated;

- category no. 4 (Mistake-contingent technical instruction) - 2 items (no. 16 and 28) did not fall into this category, 1 item (no. 40) was not properly formulated due to the category;

- category no. 7 (Ignoring mistakes) - contained all negative items; we believe also that children are not able to adequately assess this speech of the coach;

- category no. 8 (Keeping control) - 2 items (no. 20 and 32) from this category have been incomprehensible for children; 1 item (no. 44) did not fall into this category; we believe that even here children are not able to assess what the coach is doing or not doing in order to maintain control;

- category no. 10 (General encouragement) - 3 items (no. 22, 34 and 46) according to our findings did not fall in this category;

- category no. 11 (Organization) - 3 items (no. 11, 23 and 47) were incomprehensible to the respondents; this trainer's skill is particularly important in order to keep children motivated and excited for the sport; we believe that not even here younger children are able to adequately respond.

Finally we used 28 items and 6 factor structure which we evaluated through procedure of exploratory factor analysis to confirm general picture of modify CBAQ - used items: 1, 3, 5, 6, 12, 13, 15, 16, 17, 18, $21,22,24,25,27,28,29,30,33,34,36,37,39,41,42$, $45,46,48$.

An examination of the goodness of fit information for the EFA results produces relatively clear results. Using the recommended cut off values of fit indices 6 factor solution is supported. We decided to use 6 factor EFA model as basic also due to transparent dividing of items to factors. What is clear from TABLE 4 is that the 1-5 factor solution is not supported by the pattern of all fit indices.

Furthermore, the 6 factor solutions presented in TABLE 4 produce general meaningful solutions, thus we finally decided to take 6 factor EFA model as a basic model for CFA.

However, this model had of lack fit for the model and moreover, we also had to reject this 6 factor model due to the Heywood case. Correlation between Punishment and Punitive technical instruction was higher than value 1 (1.132). Furthermore, we found poor construct validity lower than 0.40 of items $5,12,15,16,18,21$, $22,27,33,34,46$. This fact showed that 6 factor model with 28 items is not sufficient. Therefore, we suggested to assess content of each of poor item and tried to remove them to other constructs. However, the meaning of indicators was so specific that finally it was decided to delete poor items from 6 factor model and suggest a new structure.

Based on the above mentioned steps, modified version of the CBAQ questionnaire was created, it consists of 6 constructs containing a total of 17 items.

TABLE 3

Exploratory factor analysis models of modified version of CBAQ with 28 items

\begin{tabular}{|c|c|c|c|c|c|c|}
\hline Model & Chi-square & df & CFI & TLI & RMSEA & SRMR \\
\hline 1 factor & 754.399 & 495 & 0.661 & 0.639 & 0.074 & 0.131 \\
\hline 2 factors & 591.875 & 463 & 0.832 & 0.808 & 0.054 & 0.101 \\
\hline 3 factors & 519.089 & 432 & 0.886 & 0.861 & 0.046 & 0.089 \\
\hline 4 factors & 452.442 & 402 & 0.934 & 0.913 & 0.038 & 0.078 \\
\hline 5 factors & 407.760 & 373 & 0.948 & 0.928 & 0.033 & 0.069 \\
\hline 6 factors & 368.642 & 345 & 0.969 & 0.953 & 0.029 & 0.061 \\
\hline
\end{tabular}

Legend: $\mathrm{CFI}=$ Comparative fit index (recommended value $\geq 0.95)$, TLI $=$ Tucker-Lewis index (recommended value $\geq 0.95)$, RMSEA $=$ Root Mean Square of Approximation (recommended value $\leq 0.06$ ), SRMR $=$ Standardized Root Mean Residual (recommended value $\leq 0.07$ ) 
TABLE 4

CFA 6 factor model of modified version of CBAQ with 28 items

\begin{tabular}{|c|c|c|c|c|c|c|}
\hline Model & Chi-square & df & CFI & TLI & RMSEA & WRMR \\
\hline 6 factors & 469.282 & 362 & 0.828 & 0.808 & 0.085 & 0.981 \\
\hline
\end{tabular}

Legend: $\mathrm{CFI}=$ Comparative fit index (recommended value $\geq 0.95)$, TLI $=$ Tucker-Lewis index (recommended value $\geq 0.95)$, RMSEA = Root Mean Square of Approximation (recommended value $\leq 0.08$ ), WRMR = Weighted Root Mean Square Residual (recommended value $\leq 1.00)$

\section{TABLE 5}

CFA 6 factor model of modified version of CBAQ with 17 items

\begin{tabular}{|c|c|c|c|c|c|c|}
\hline Model & Chi-square & Df & CFI & TLI & RMSEA & WRMR \\
\hline 6 factors & 206.679 & 137 & 0.897 & 0.872 & 0.072 & 0.937 \\
\hline
\end{tabular}

Legend: CFI = Comparative fit index (recommended value $\geq 0.95)$, TLI $=$ Tucker-Lewis index (recommended value $\geq 0.95)$, RMSEA = Root Mean Square of Approximation (recommended value $\leq 0.08$ ), WRMR = Weighted Root Mean Square Residual (recommended value $\leq 1.00)$

\section{TABLE 6}

CFA 5 factor model of modified version of CBAQ without factor "General technical instruction"

\begin{tabular}{|c|c|c|c|c|c|c|}
\hline Model & Chi-square & df & CFI & TLI & RMSEA & WRMR \\
\hline 5 factors & 104.193 & 109 & 0.964 & 0.953 & 0.056 & 0.712 \\
\hline
\end{tabular}

Legend: $\mathrm{CFI}=$ Comparative fit index (recommended value $\geq 0.95), \mathrm{TLI}=$ Tucker-Lewis index (recommended value $\geq 0.95), \mathrm{RMSEA}=$ Root Mean Square of Approximation (recommended value $\leq 0.08$ ), WRMR = Weighted Root Mean Square Residual (recommended value $\leq 1.00$ )

Despite deleting poor items, this 6 factor model also showed poor fit values at index CFI and TLI, which was caused due to problem with latent variable General technical instruction factor which contained only two indicators 28,45 . This fact can be problematic in identifying the model, because for identification of latent variables in sample size $\mathrm{N}=100$ it is needed to have at least three observed variables (Kline, 2011).

\section{Fig. 2}

Modified 6 factor model structure of CBAQ questionnaire with 17 items

\begin{tabular}{|c|c|c|c|}
\hline & Categories & Items & \\
\hline 1. & Reinforcement & $1,25,37$ & 1. \\
\hline 3. & $\begin{array}{l}\text { Mistake-contingent } \\
\text { encouragement }\end{array}$ & $3,13,39$ & 3. \\
\hline 5. & Punishment & $17,30,42$ & 5. \\
\hline 6. & $\begin{array}{l}\text { Punitive technical } \\
\text { instruction }\end{array}$ & $6,18,29$ & 6. \\
\hline 9. & $\begin{array}{l}\text { General technical } \\
\text { instruction }\end{array}$ & 28,45 & 9. \\
\hline 12. & General communication & $24,36,48$ & 12. \\
\hline
\end{tabular}

Therefore, we decided to reject this model. For our next analysis we deleted this factor with two items and repeat CFA with remaining five factors structure.

With regard to an important characteristic of General technical instruction factor we suggest that this factor should be in further study re-modeled along with reformulated items that contain negatives about which we discussed above.

Fig. 3

Modified 5 factor model structure of CBAQ questionnaire

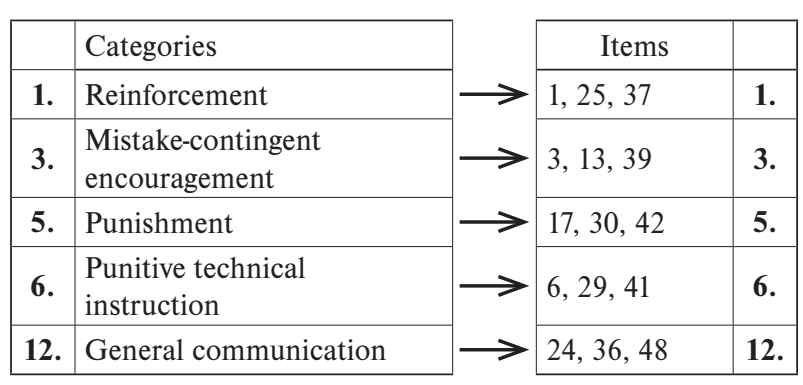


Fig. 4

Structural model of modified version of CBAQ with five factors, squares represent individual items, ovals latent factors, the arrows represent relationship between items and latent variables

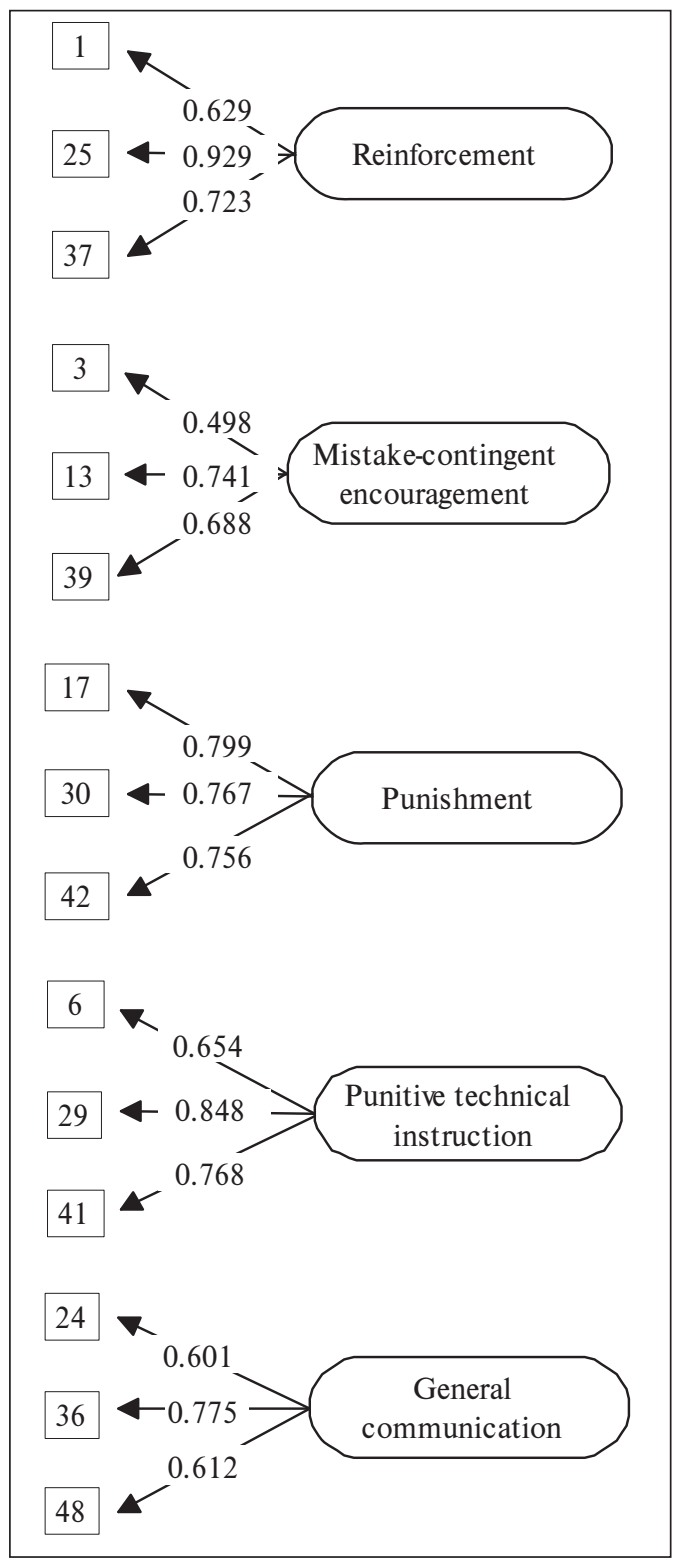

\section{TABLE 7}

Correlation matrix of latent variables (factors) with highlighted stronger correlations between factors in modified version

\begin{tabular}{|l|c|c|c|c|c|}
\hline Rei & Rei & Mi-co-e & Pun & Pun-t $-i$ & Ge-com \\
\hline Rei & 1 & & & & \\
\hline Mi-co-e & $\mathbf{0 . 7 0 2}$ & 1 & & & \\
\hline Pun & -0.344 & -0.337 & 1 & & \\
\hline Pun-t- $i$ & -0.459 & -0.569 & $\mathbf{0 . 6 8 2}$ & 1 & \\
\hline Ge-com & 0.189 & 0.569 & 0.157 & -0.049 & 1 \\
\hline
\end{tabular}

From the results of this model is seen that the 5 factor model with 15 items showed significant improvement of all fit indices with values at acceptable or even very good levels. The 5 factor model shows conceptually clear factor loading patterns that are mostly consistent.

\section{DISCUSSION}

Factorial validity and fit of the model of modify version CBAQ

The outcomes from structural equation modeling (Fig. 4) of modified version of CBAQ suggested that a five dimensional structure with the 15 items fit the data best and indicated good fit of the model. In the modified version of CBAQ which contains five factors and 18 items the index RMSEA was on the level 0.056 which expresses good fit of the model. This value was much closer in comparing of RMSEA $=0.052$ in the original study Martin and Barnes (1999). Value of CFI index of fit was also increased from 0.600 to acceptable the value 0.964. As well as chi-square $=104.193$, $\mathrm{TLI}=0.953$ and $\mathrm{WRMR}=0.712$ showed rather strong improvement for fit of the model.

These results were achieved despite of sample size $\mathrm{N}=100$ which was not entirely satisfactory. From Fig. 4 is also evident that there is one indicator which has factor validity, on relatively poor level 0.50 , item no. 3 at latent variable Mistake-contingent encouragement. We tried to analyze 5 factor model with interchanged item no. 16 for item no. 3 for its similar content, but after that we found a much worse fit of the model. Therefore we decided to leave this indicator in structure for its important uniqueness. Additionally, in the modified structural model we discovered only two stronger correlations between latent variables which are measuring similar but not the same latent areas.

\section{Reliability}

In approximation of generic reliability by coefficient McDonald $\omega$ in modified version of CBAQ we found a narrowing of reliability coefficients range values

\section{TABLE 8}

Generic reliability of latent variables in modified version of CBAQ

\begin{tabular}{|l|c|}
\hline Constructs & $\begin{array}{c}\text { Generic reliability, } \\
\text { McDonald } \omega\end{array}$ \\
\hline Reinforcement & $\mathbf{0 . 8 2}$ \\
\hline Mistake-contingent encouragement & 0.69 \\
\hline Punishment & $\mathbf{0 . 8 3}$ \\
\hline Punitive technical instruction & $\mathbf{0 . 8 0}$ \\
\hline General communication & 0.71 \\
\hline
\end{tabular}


0.69-0.83. These results showed improvement in comparison with results from the Czech version of original CBAQ. Coefficients of approximation of generic reliability were acceptable at factors Reinforcement $\omega=0.82$, Punishment $\omega=0.83$, Punitive technical instruction $\omega=0.80$, General communication $\omega=0.71$. Latent variable Mistake-contingent encouragement $\omega=0.69$ was only one subscale which showed reliability lower than 0.70 .

\section{CONCLUSION}

We can conclude that structural equation modeling did not confirm similar coefficients of diagnostics quality of the Czech version of CBAQ in the original twelve factors and 48 items model. We found a lot of problems with understanding and the meaning of some of items which were unsuitable for participants (e.g. item number 11, 20, 23, 25, 31, 32, 40, 42, 43, 46, 47). Furthermore, we found problems with items not corresponding to related factors (e.g. 9, 16, 22, 23, 26, 28, $30,34,44,46)$. Results from original model completely indicated under average fit of the model. Due to average value RMSEA on the level 0.082 , under average value of $\mathrm{CFI}=0.600, \mathrm{TLI}=0.555$ and high correlations between. We decided to re-evaluate our data with a restricted number of factors and items in modified version of CBAQ. After the procedure of confirmatory factor analysis we finally determined five factor structure with 15 items which contribute to an improving of psychometric properties of this modified version of CBAQ. Results of this modified version of CBAQ indicated a good fit of the model at index RMSEA $=0.056$ and acceptable fit value of CFI $=0.964, \mathrm{WRMR}=0.712$ despite of that size of research sample $(N=100)$ was not satisfactory.

This study had a pilot character and we realize problems with loosing information due to very restricted numbers of items in the modified version. However, we suggest that the final 5 factor 15 items version could be made as the basis for a future full standardized Czech version of CBAQ. We assume that for sufficient standardization would be necessary to repeat process of content validity reformulated items (no. 2, 5, 7, 9, 11, 14, $19,20,21,22,23,26,31,32,33,34,38,40,43,47)$, so that, you remove negatives from them and problematic words as well and that certain items will be reformulated so that they will describe more clearly the category, they fall into.

After that, we suggest re-evaluation of the Czech version of CBAQ by means of structural equation modeling with a bigger research sample at least $(\mathrm{N}=600)$ from design selected population of volleyball athletes age 10-16 played regional championship or Czech Cup and create a final version of CBAQ for the Czech population.

\section{ACKNOWLEDGEMENTS}

This project is supported by the programs SVV265 602 and 261105.

\section{REFERENCES}

Amorose, A. J. (2007). Coaching effectiveness. In M. S. Hagger \& N. L. D. Chatzisarantis (Eds.), Intrinsic motivation and self-determination in exercise and sport (pp. 209-227). Leeds: Human Kinetics.

Amorose, A. J., \& Horn, T. S. (2011). Pre to post-season changes in intrinsic motivation of the first year college athletes: Relationships with coaching behavior and scholarship status. Journal of Applied Sport Psychology, 13, 355-373.

Baker, J., Yardley, J., \& Côté, J. (2003). Coach behaviors and athlete satisfaction in team and individual sports. International Journal of Sport Psychology, 34, 226-239.

Behling, O., \& Law, K. S. (2000). Translating questionnaires and other research instruments: Problems and solutions. Thousand Oaks, CA: Sage.

Bentler, P. M. (1990). Comparative fit indexes in structural models. Psychological Bulletin, 107, 238-246.

Black, S. J., \& Weiss, M. R. (1992). The relationship among perceived coaching behaviors, perceptions of ability, and motivation in competitive age group swimmers. Journal of Sport \& Exercise Psychology, 14, 309-325.

Browne, M. W., \& Cudeck, R. (1993). Alternative ways of assessing model fit. In K. A. Bollen \& S. J. Long (Eds.), Testing structural equation models (pp. 136-162). Newbury Park: Sage.

Chelladurai, P. (1990). Leadership in sports: A review. International Journal of Sport Psychology, 21(4), 328-354.

Chelladurai, P. (1993). Leadership. In R. N. Singer, M. Murphy, \& L. Tennant (Eds.), Handbook of Research on Sport Psychology (pp. 647-671). New York: Macmillan.

Chelladurai, P., \& Saleh, S. D. (1978). Preferred leadership in sports. Canadian Journal of Applied Sport Sciences, 3(2), 85-92.

Chelladurai, P., \& Saleh, S. D. (1980). Dimensions of leader behavior in sports: Development of a leadership scale. Journal of Sport Psychology, 2, 34-45.

Gillet, N., Vallerand, R. J., Amoura, S., \& Baldes, B. (2010). Influence of coaches' autonomy support on athletes' motivation and sport performance: A test of the hierarchical model of intrinsic and extrinsic motivation. Psychology of Sport and Exercise, 11, 155-116.

Hines, A. M., \& Snowden, L. R. (1993). Survey and interviewing procedures: Cross-cultural validity 
and the use of protocol analysis. In J. E. Trimble, C. S. Bolek, \& S. Niemcryk (Eds.), Conducting crosscultural substance abuse research: Emerging strategies and methods (pp. 25-45). Newbury Park, CA: Sage.

Hu, L., \& Bentler, P. M. (1999). Cut off criteria for fit indices in covariance structure analysis: Conventional criteria versus new alternatives. Structural equation modeling, 6, 1-55.

Jöreskog, K. G., \& Sörbom, D. (1988). LISREL 7 A guide to the program and applications (2nd ed.). Chicago: SPSS.

Keith, T. A., \& Witta, E. L. (1997). Hierarchical and cross-age confirmatory factor analysis of the WISC-III: What does it measure? School Psychology Quarterly, 12, 89-107.

Kline, R. B. (2011). Principles and practice of structural equation (3rd ed.). New York: Guildford Press.

Kravig, S. D. (2003). Coaching behavior preferences of interscholastic athletes. Master thesis, University of North Texas, College of Education, Denton.

Lawley, D. N., \& Maxwell, A. E. (1971). Factor analysis as a statistical method (2nd ed.). London: Butterworths.

Martin, S. B., \& Barnes, K. (1999). Coaching behavior questionnaire. Unpublished manual, University of North Texas, Denton.

Martin, S. B., Barnes, K., Kravig, S. D., \& Johnson, M. S. (2005). Coaching behavior preferences of interscholastic and intercollegiate athletes. Unpublished manual, University of North Texas, College of Education, Denton.

Martin, S. B., Dale, G. A., \& Jackson, A. W. (2001). Youth coaching preferences of adolescent athletes and their parents. Journal of Sport Behavior, 24, 197-212.

Martin, S. B., Jackson, A. W., Richardson, P. A., \& Weiller, K. H. (1999). Coaching preferences of adolescent youths and their parents. Journal of Applied Sport Psychology, 11, 247-262.

McDonald, R. P. (1991). Faktorová analýza a př́buzné Metody v psychologii (P. Blahuš, Trans.) (1. ed.). Praha: Academia.

Mondello, M. J., \& Janelle, C. M. (2001). A comparison of leadership styles of head coaches and assistant coaches at a successful division I athletic program. International Sports Journal, 5, 40-49.

Muthén, B. (1984). A general structural equation model with dichotomous, ordered categorical and continuous latent variable indicators. Psychometrika, 49, 115-132.

Muthén, L. K., \& Muthén, B. O. (2010). Mplus user's guide (6th ed.). Los Angeles, CA: Muthén \& Muthén.

Rao, C. R., \& Sinharay, S. (2007). Handbook of statistics 26 psychometrics. North Holland: Elsevier.
Smith, R. E., Smoll, F. L., \& Hunt, E. B (1977). A system for the behavioral assessment of coaches. Research Quarterly, 48, 40-47.

Steiger, J. H. (1990). Structural model evaluation and modification: An internal estimation approach. Multivariate Behavioral Research, 25, 173-180.

Trucker, L. R., \& Lewis, C. (1973). The reliability coefficient for maximum likelihood factor analysis, $P s y$ chometrika, 38, 1-10.

\section{PILOTNÍ TESTOVÁNÍ STRUKTURY ČESKÉ VERZE DOTAZNÍKU COACHING BEHAVIOR ASSESSMENT QUESTIONNAIRE}

(Souhrn anglického textu)

VÝCHODISKA: Ve sportovním prostředí je obecně uznáván názor, že trenér hraje důležitou roli při dosahování týmového úspěchu (Amorose \& Horn, 2011). Scott Martin a Kelly Barnes vytvořili v roce 1999 dotazník Coaching Behavior Assessment Questionnaire, který vychází z CBAS (Smith a kol., 1977) a LSS (Chelladurai \& Saleh, 1978, 1980). V současné době není v České republice podobný diagnostický nástroj pro hodnocení chování trenéra.

CÍLE: Cílem této pilotní studie bylo přeložit a ohodnotit strukturu dotazníku CBAQ metodou strukturálního modelování pro populaci dětí ve věku 10-16 let.

METODIKA: Pro účel překladu dotazníku byla použita modifikovaná metoda př́mého překladu (Behling \& Law, 2000). Dotazník vyplnilo 100 účastníků ve věku 10-16 let, 63 dívek (průměrný věk 13,02, $\mathrm{SD}=2,10$ ), 37 chlapců (průměrný věk $13,27, \mathrm{SD}=1,37$ ). Pro analýzu dat byla použita exploratorní a konfirmační faktorová analýza.

VÝSLEDKY: Původní model byl testován za účelem ověření struktury a diagnostické kvality tohoto nástroje. Výsledky původního 12 faktorového modelu CBAQ ukázaly slabou shodu modelu s podprůměrnými hodnotami indexů shody RMSEA $=0,082, \mathrm{CFI}=0,600$ a také nízké koeficienty generické reliability. $\mathrm{Z}$ tohoto důvodu jsme se rozhodli pro re-analýzu dat, ze které byla vytvořena modifikovaná 5 faktorová struktura CBAQ. Tento 5faktorový model s omezeným počtem položek ukázal nejlepší hodnoty indexů shody RMSEA $=0,056$, CFI $=0.964$ a také akceptovatelné hodnoty generické reliability.

ZÁVĚRY: Tato studie měla pilotní charakter, uvědomujeme si proto, že snížení velkého počtu položek u této modifikované verze vedlo ke ztrátě informace. Přesto se domníváme, že by tato finální 5 faktorová verze s 15 položkami mohla tvořit základ pro budoucí připravovanou plně standardizovanou českou verzi CBAQ.

Klićová slova: chování trenéra, mezikulturní validizace, face-validita, obsahová validita, strukturální modelování, reliabilita. 


\section{Mgr. Veronika Baláková}

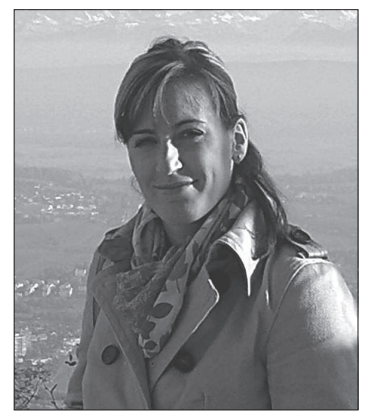

Charles University

Faculty of Physical Education and Sport

José Martího 31

16252 Praha 6

Czech Republic

\section{Education and previous work experience}

2003-2008 - Faculty of Physical Education and Sport, Charles University in Prague - Master degree in Pedagogy for secondary school with specialization in Physical education and Psychology.

Since 2008 - Faculty of Arts, Charles University in Prague - Ph.D. student.

2009 - Faculty of Humanities and Social Sciences, University of Glamorgan - Pontypridd, Wales, United Kingdom (educational stay).

Since 2012 - Faculty of Education, Charles University in Prague (lecturer).

Since 2010 - Faculty of Science, Charles University in Prague (lecturer).

Since 2008 - Czech Association of Sport Psychologists (sport psychologist).

\section{First-line publication}

Baláková, V. (2008). Komunikační dovednosti trenéra volejbalu. Diplomová práce, Univerzita Karlova, Fakulta tělesné výchovy a sportu, Praha.

Baláková, V. (2010). Videotrénink interakcí - metoda na podporu a rozvoj sociálních dovedností trenérů. In V. Baláková \& J. Kirchner (Eds.), Sborník př́spěvků $z$ konference Psychologie sportu v praxi aneb Cesty ke sportovnímu úspěchu (pp. 127-139). Praha: Filozofická fakulta UK v Praze.

Baláková, V. (2011). Rozvoj sociálních dovedností sportovního trenéra pomocí VTI. In D. Heller \& P. Michálek (Eds.), Sborník príspěvků z konference Psychologické dny 2010: Cesty psychologie a psychologie cest (pp. 475-487). Praha: Provozně ekonomická fakulta ČZU v Praze a Českomoravská psychologická společnost.

Baláková, V. (2011). Youth volleyball trainer's social skills and their development by video interaction guidance [Abstract]. In S. Serpa, N. Teixeira, M. J. Almeida, \& A. Rosado (Eds.), Sport and exercise psychology: Human performance, well-being and health (p. 399). Funchal: Institute of Sport of the Autonomous Region of Madeira, IP-RAM.

Baláková, V. (in press). Jak ovlivnit motivaci sportovce. In Sborník př́spěvkủ z konference Hry 2012.

Baláková, V. (in press). Př́padová studie - práce s trenérem volejbalu pomocí metody VTI. In Sborník príspěvků z konference Psychologické dny 2012: Prostor $v$ nás a mezi námi - respekt, vzájemnost, sdílení. 